\title{
Simulation and comparison of stream power in-channel and on the floodplain in a German lowland area
}

\author{
Song Song, Britta Schmalz, Nicola Fohrer
}

Department of Hydrology and Water Resources Management, Institute for Natural Resource Conservation, University of Kiel, Olshausenstr. 75, 24118 Kiel, Germany.

* Corresponding author. Tel.: 049-0431-8802725. Fax: 049-0431-8804083. Email: ssong@hydrology.uni-kiel.de

\begin{abstract}
Extensive lowland floodplains cover substantial parts of the glacially formed landscape of Northern Germany. Stream power is recognized as a force of formation and development of the river morphology and an interaction system between channel and floodplain. In order to understand the effects of the river power and flood power, HEC-RAS models were set up for ten river sections in the Upper Stör catchment, based on a $1 \mathrm{~m}$ digital elevation model and field data, sampled during a moderate water level period (September, 2011), flood season (January, 2012) and dry season (April, 2012). The models were proven to be highly efficient and accurate through the seasonal roughness modification. The coefficients of determination $\left(\mathrm{R}^{2}\right)$ of the calibrated models were $0.90,0.90,0.93$ and 0.95 respectively. Combined with the continuous and long-term data support from SWAT model, the stream power both in-channel and on the floodplain was analysed. Results show that the 10-year-averaged discharge and unit stream power were around 1/3 of bankfull discharge and unit power, and the 10-year-peak discharge and unit stream power were nearly 1.6 times the bankfull conditions. Unit stream power was proportional to the increase of stream discharge, while the increase rate of unit in-channel stream power was 3 times higher than that of unit stream power on the floodplain. Finally, the distribution of the hydraulic parameters under 10-years-peak discharge conditions was shown, indicating that only $1-10 \%$ of flow stream was generated by floodplain flow, but $40-75 \%$ volume of water was located on the floodplain. The variation of the increasing rate of the stream power was dominated by the local roughness height, while the stream power distributed on the floodplain mainly depended on the local slope of the sub-catchment.
\end{abstract}

Keywords: HEC-RAS model; In-channel flow; Floodplain flow; Unit stream power; Inundation area.

\section{INTRODUCTION}

Recent studies have recognized the importance of river flow analysis and the need to understand the interaction with the river bed and the ecosystem (Sponseller et al., 2010; Wu et al., 2010). More accurate information about river flow and floodplain flow is important for analyzing the alluvial and hydrological effects of the river systems, including water pollutants diffusion, hydraulic construction, water quality distribution and prediction, river resource management, flood estimation and flood damage prevention, etc. (Brocca et al., 2011; Christian et al., 2013; Lau and Ghani, 2012; Posey, 2009). The driving force of these flow behaviors is commonly expressed as stream power (Jain et al., 2006). Stream power is defined as the time rate of expenditure of potential energy (or supply) when the water travels downstream (Rhoads, 1987). The stream power of the high-magnitude flood is more powerful to cause the major, abrupt morphological change in channel and on the floodplain (Vocal Ferencevic and Ashmore, 2012). Total stream power per unit channel length, or so called unit stream power $(\Omega, \mathrm{W} / \mathrm{m})$ is mathematically defined as,

$$
\Omega=\gamma \mathrm{QS}_{\mathrm{e}}
$$

Here, $\gamma$ is the specific weight of water $(\mathrm{N}), Q$ is discharge $\left(\mathrm{m}^{3} / \mathrm{s}\right)$ and $S_{e}$ is energy slope, which can be approximated by the water surface slope (Barker et al., 2009; Knighton, 1999).

Europe has been under arising threat of floods, especially high-magnitude floods in the last years (Marchi et al., 2010b). Analysis of the gauged data from 145 stations across Germany suggest an increasing flood hazard during the last five decades, and these observed flood behavior trends are proven to be mainly climate-driven (Petrow and Merz, 2009). Most notable increases in flood losses across the different climate future scenarios are projected for countries in Western Europe (Dankers and Feyen, 2009). The assessment of river risk based on climate scenarios in parts of Germany estimated that the small and medium flood discharge will increase by around $40-50 \%$ while the 100 -year floods is going to increase by $15 \%$ in 2050 (Kundzewicz et al., 2010).

Bankfull discharge is the maximum flow volume the channel can carry and is identified as an important parameter for studying river morphology, flood dynamics and their ecological impacts (Navratil et al., 2006). Discharge above this split value leads to the interaction process between in-channel and floodplain flow and triggers the additional energy losses due to the expansion and friction change of the overbank flow (Knight and Shiono, 1996). The flood magnitude determined the flood wave propagation and attenuation during the overbank flow process (Archer, 1989). Although the flow energy variation with discharge gained very little attention according to the literature review, quantifying the bankfull stream power and the variation of stream power with discharge would provide significant insights into the stream and flood events development (Vocal Ferencevic and Ashmore, 2012).

Considering the increasing flood risk and the important role of stream power in the function of fluvial systems, the spatial flow and flood energy expenditure deserve to be extended by experimental or modeling approaches (Horritt and Bates, 2002; Knighton, 1999). Earlier studies have paid attention to estimate the longitudinal distribution of the stream power from both point-location cross section studies and continuous profile studies (Barker et al., 2009; Jain et al., 2006; Knighton, 1999). The reconstruction of stream peak discharge and flood power at 
different cross sections along the main stream provide the longitudinal distribution of stream power on basin scale (Marchi et al., 2010a). Modeling approaches have been adopted in exploring the downstream distribution of the stream power and pointed out that the variability of stream power in headwater reaches is explained by discharge variability, while the variability in midstream and downstream reaches governed by the high variability of channel gradient (Evans et al., 2009). It has been revealed in the literature that the latitudinal distribution of flow and flood were relatively less studied in the last decades. Traditionally stream power data measured from limited cross sections is not sufficiently enough to describe the energy distribution of the flow in-channel and on the floodplain (Barker et al., 2009). Modeling approaches would be a highly efficient supplement in quantifying the latitudinal discharge and energy expenditure.

In this study, we show a combined model approach to evaluate latitudinal stream power distribution. The high precise 1Dhydraulic models in the Upper Stör catchment in Northern German lowland were established, 1) to quantify the variation of stream power both in channel and on the floodplain; 2) to exam the latitudinal distributions of the stream power in channel and on the floodplain, and 3) try to investigate the cause of the different distribution patterns among the sub-catchments.

\section{STUDY AREA AND METHODOLOGY Study area}

The Upper Stör River catchment is part of the lowland area located in the middle of Schleswig-Holstein/Northern Germany. The catchment stretches over $35 \mathrm{~km}$ in the east-west direction and $19 \mathrm{~km}$ in the north-south direction covering a drainage area of $468 \mathrm{~km}^{2}$ (Fig. 1, Table 1). In most of the catchment the gradients are usually smaller than $1^{\circ}$, except southwestern part, which has gradients of more than $3^{\circ}$ (LVermGeoSH, 1995).

The catchment was divided into 21 sub-catchments covered every tributary, but only ten of them were selected in our study (Fig. 1). The $300 \mathrm{~m}$ river sections at the outlet of the selected sub-catchments were measured. A criterion for sub-catchment and river section selection was that the sites diversity had to be sufficiently enough to reveal the catchment conditions, while some major disturbances or obstacles need to be avoided.

The sites had to be easily accessible and suitable to measure with a flow meter. According to such criteria, the subcatchments we chose sized from $32 \mathrm{~km}^{2}$ to $461 \mathrm{~km}^{2}$, and the adjacent floodplains were covered by pasture, forest, arable land and construction land. The slope, area and the roughness of the adjacent floodplain at each river section was given in Table 1 . The slope varied from $-0.2 \%$ to $0.55 \%$ on the floodplain, and ranged from $-0.05 \%$ to $0.43 \%$ in the channel. At most river sections, the floodplain roughness height is higher than the in-channel roughness.

\section{Model cascade and data transfer SWAT and HEC-RAS Model description}

The SWAT model is a continuous, long-term, semidistributed parameter model that can simulate surface and subsurface flow, soil erosion and sediment deposition, and nutrient movement through watersheds (Arnold et al., 1998). The soil water balance equation is the basis of hydrological modeling. The land phase of the hydrological cycle and the routing of runoff through the river network is the major framework of the SWAT model. The simulated processes include surface runoff, infiltration, evaporation, plant water uptake, lateral flow, and percolation to shallow and deep aquifers (Coffey et al., 2010; Luo et al., 2012). Discharge is one of the outputs of the flow routing, and has proven to be successfully linked to other models (e.g., MODFLOW) to provide background data for the model development (Johnston et al., 2011; Kiesel et al., 2013; Zhang, 2011).

Hydrologic Engineering Centers River Analysis System (HEC-RAS) developed by the US Army Corps of Engineers is an integrated 1-D hydraulic model for interactive use in a multitasking environmental management (Brunner, 1995). Although the main function of this model is to simulate steady/unsteady river dynamics, sediment transportation and water quality dynamics (Hicks and Peacock, 2005; Horritt and Bates, 2002; Yang et al., 2006), it is also adopted as an effective stream power estimation tool (Vocal Ferencevic and Ashmore, 2012).

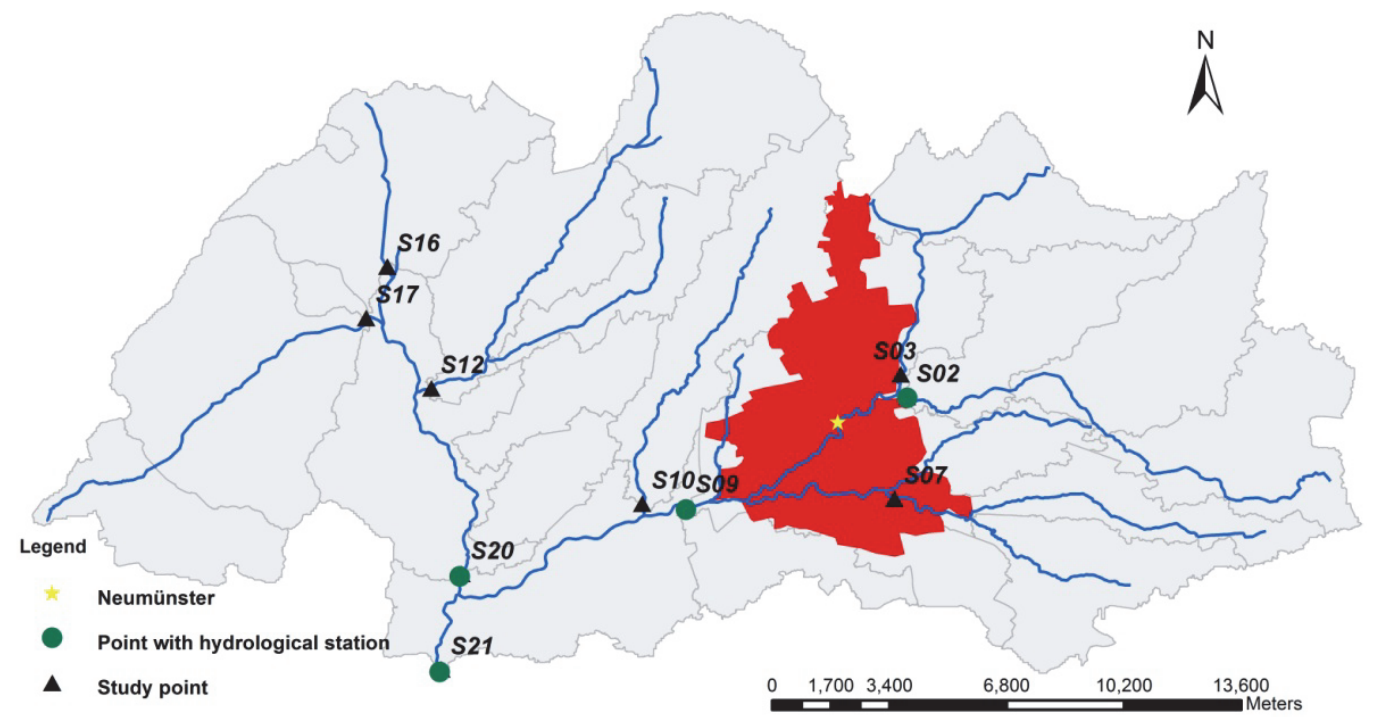

Fig. 1. The location of Upper Stör catchment and study river sections. 
The boundary condition in forms of flow series, normal depth, stage series or rating curve is the essential input during the steady and unsteady flow analysis process. The steady and unsteady flow analysis calculation bases on the fundamental hydraulic equations, including the continuity equation, energy equation, and flow resistance equation (Kasper, 2005). The adoption of resistance equation in HEC-RAS model is criticized as being the overly sensitive factor in many researches (Pappenberger et al., 2005; Parhi, 2013; Parhi et al., 2012). The uncertainty in flow characteristics modeling is not only caused by the calibration process of the roughness parameter, but also because of the difficulty in selecting the 'correct' roughness in practical application (Pappenberger et al., 2005; Parhi, 2013; Parhi et al., 2012).

The suitability and accuracy of the HEC-RAS model have been proven to be comparable to other 1D (Hicks and Peacock, 2005; Knebl et al., 2005) and 2D hydrological models (Bates and De Roo, 2000; Hervouet, 2000; Horritt and Bates, 2002). Besides the single model approach, the integrated model approaches aimed at linking the HEC-RAS model with other models to extract the best of each individual model component have been primarily pursued. Promising results were yielded in integrating sediment output of the SWAT model (Soil and Water Assessment Tool) (Arnold et al., 1998) to HEC-RAS model and BIOMOD (Thuiller, 2003) model (Jähnig et al., 2012; Kuemmerlen et al., 2012; Schmalz et al., 2012; Strehmel, 2011).

\section{Data transfer}

We integrated the distributed eco-hydrological model with the 1-D hydraulic model to simulate the variation of the unit stream power in the Upper Stör catchment. The SWAT model is an adequate supplement to the HEC-RAS model in hydraulic dynamic modeling, providing basic discharge input. The longterm continuous daily flow output from SWAT model of every sub-catchment was adopted as the boundary condition input in HEC-RAS model. The SWAT model for the study area has been set up and well calibrated until 2010 (Pott, 2014). Preliminary calibration and validation of the SWAT daily simulations yielded an averaged Nash-Sutcliffe of 0.83 and an averaged coefficient of determination $\left(\mathrm{R}^{2}\right)$ of 0.88 at the outlet of the Upper Stör catchment (Fig. 2). This proved the efficient performance of the SWAT model and it's suitability to work as the HEC-RAS input data base.

\section{Data collection}

Cross-sectional profiles of water surface width, depth, velocity and discharge for seven cross sections evenly distributed along the $300 \mathrm{~m}$ river sections at the outlet of the ten selected sub-catchments were collected. Field campaigns were carried out during the moderate water level period (September, 2011), and surveys were then repeated at the same cross sections during flood season (January, 2012) and dry season (April, 2012) respectively at the ten selected river sections of the Upper Stör River (Fig. 1). The river depth, velocity and discharge were measured with the FlowSens device (SEBA Hydrometrie, Germany) during dry season and an Acoustic Doppler device called Qliner (ADQ, OTT Company, Kempten/Germany) during moderate water leve1 period and flood season. The accuracy and applicability of both equipment has been proven in a previous study (Song et al., 2012). Additionally bank elevation, bank vegetation and sediment condition were mapped in the first field campaign in September 2011 in order to set up the 1-D hydraulic HEC-RAS model. Bank elevation together with cross-sectional depth determined the geometry of every cross section. Bank vegetation and channel sediment were then transformed into roughness height according to the conversion relationship (Chow, 1959).

\section{The setup of HEC-RAS Model}

Stream channel cross sections were obtained from the Laboratory's computer-based geographic information system (ArcGIS 9.3) in addition to field survey data basis (Fig. 3). Topographic data of floodplains were automatically extracted from the Digital Elevation Model (DEM) with $1 \mathrm{~m}$ resolution using HEC-geoRAS, an ArcView extensive capability developed by the USACE-HEC. These cross-sectional features containing the geo-referenced information were then exported to the HEC-RAS model, in order to set up the main river geometry system. The HEC-RAS models for each river section were first produced, and then the roughness factor and the edited river bed geometry were imported. The complete procedure is shown in Fig. 3.

\section{MODEL CALIBRATION AND VALIDATION}

Model calibration and validation are necessary and critical steps in the model application for parameter evaluation and

Table 1. Characteristics of the selected ten sub-catchments.

\begin{tabular}{lccccccccc}
\hline Site & Catchment & \multicolumn{3}{c}{ Slope (\%) } & \multicolumn{3}{c}{ Land use \& (Roughness Height) } & \multicolumn{2}{c}{ Area $\left(\mathrm{m}^{2}\right)$} \\
No. & size $\left[\mathrm{km}^{2}\right]$ & LOB & CH & ROB & LOB & CH & ROB & LOB & ROB \\
\hline S02 & 70.09 & 0.40 & 0.21 & 0.55 & C $(0.10)$ & 0.05 & P $(0.07)$ & 187.40 & 144.20 \\
S03 & 30.98 & 0.33 & 0.20 & 0.33 & F $(0.12)$ & 0.04 & F $(0.12)$ & 1.00 & 64.67 \\
S07 & 33.29 & 0.40 & 0.09 & 0.50 & C $(0.10)$ & 0.06 & F $(0.10)$ & 30.67 & 149.17 \\
S09 & 196.05 & 0.20 & 0.43 & 0.10 & C $(0.09)$ & 0.06 & P $(0.07)$ & 1.17 & 256.33 \\
S10 & 32.34 & 0.33 & 0.10 & 0.40 & P $(0.07)$ & 0.04 & C $(0.09)$ & 24.83 & 16.50 \\
S12 & 60.63 & 0.33 & 0.25 & 0.17 & C $(0.08)$ & 0.05 & P $(0.09)$ & 0.00 & 278.50 \\
S16 & 32.33 & 0.27 & 0.09 & 0.10 & A $(0.07)$ & 0.05 & A $(0.07)$ & 0.00 & 0.00 \\
S17 & 56.92 & -0.01 & 0.05 & 0.10 & P $(0.07)$ & 0.04 & P $(0.07)$ & 209.83 & 73.67 \\
S20 & 203.02 & 0.10 & 0.19 & 0.13 & P (0.08) & 0.06 & A $(0.08)$ & 256.33 & 750.33 \\
S21 & 461.74 & 0.17 & 0.10 & -0.2 & P $(0.08)$ & 0.06 & P $(0.08)$ & 231.83 & 479.00 \\
\hline
\end{tabular}

Note: LOB is the left bank of the channel; $\mathrm{CH}$ is the channel; ROB is the right bank of the channel. The area refers to the submerged area in the 10year-peak flood; $\mathrm{C}$ refers to the construction land use; F means Forest; $\mathrm{P}$ is pasture land; A is arable land. 


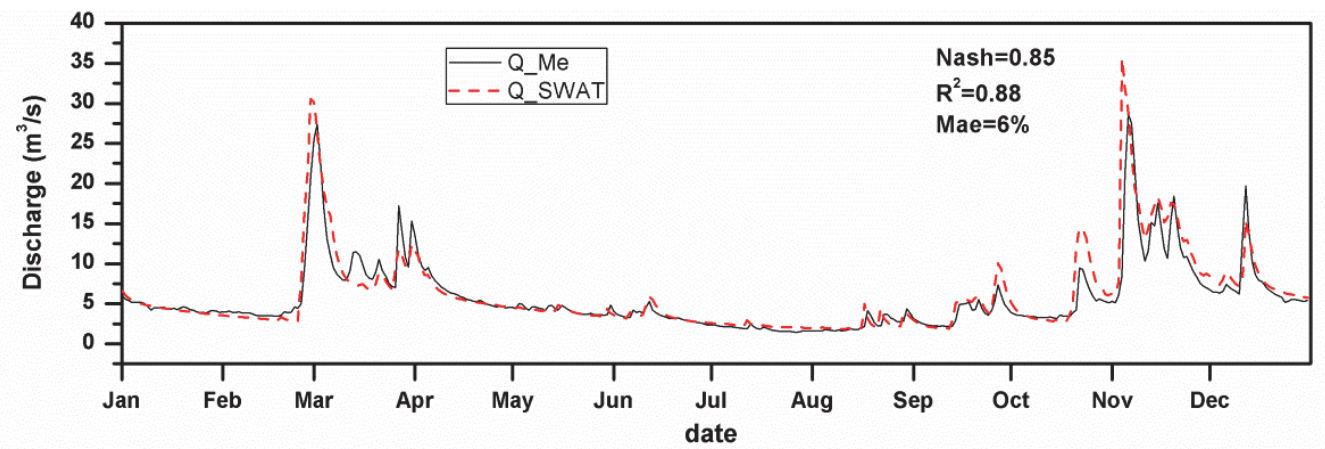

Note: Mae means absolute error of the water surface elevation; Nash, Nash-Sutcliffe efficiency.

Fig. 2. The measured and SWAT-modeled discharge at the outlet of Upper Stör catchment (S21) in 2010.

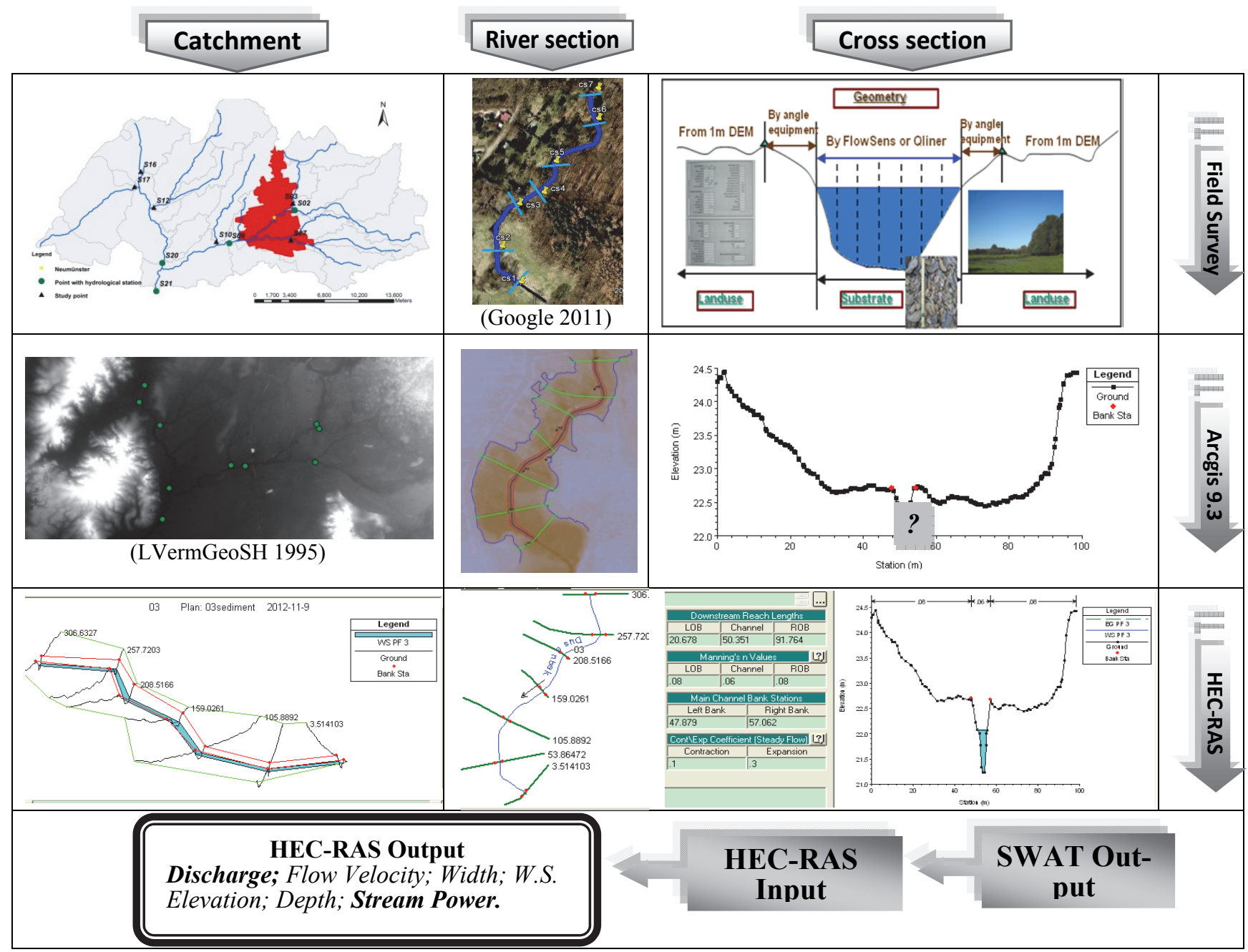

Fig. 3. Flow chart of HEC-RAS model setup.

Table 2. Seasonal roughness factors of the models.

\begin{tabular}{ccccccccccccc}
\hline & JAN & FEB & MAR & APR & MAY & JUN & JUL & AUG & SEP & OCT & NOV & DEC \\
\hline S02 & 1.14 & 1.22 & 0.57 & 0.57 & 1.14 & 1.14 & 1.22 & 1.30 & 1.30 & 1.22 & 0.57 & 0.65 \\
S09 & 0.75 & 0.94 & 0.57 & 0.66 & 0.94 & 0.94 & 1.60 & 1.70 & 1.13 & 0.94 & 0.57 & 0.57 \\
S20 & 0.90 & 0.95 & 0.53 & 0.68 & 0.98 & 0.79 & 1.28 & 1.39 & 1.43 & 1.35 & 0.83 & 0.90 \\
S21 & 0.94 & 1.02 & 0.63 & 0.71 & 0.94 & 1.02 & 1.42 & 1.57 & 1.18 & 1.18 & 0.63 & 0.71 \\
Mean & $\mathbf{0 . 9 4}$ & $\mathbf{1 . 0 4}$ & $\mathbf{0 . 5 7}$ & $\mathbf{0 . 6 5}$ & $\mathbf{1 . 0 0}$ & $\mathbf{0 . 9 7}$ & $\mathbf{1 . 3 8}$ & $\mathbf{1 . 4 9}$ & $\mathbf{1 . 2 6}$ & $\mathbf{1 . 1 7}$ & $\mathbf{0 . 6 5}$ & $\mathbf{0 . 7 1}$ \\
\hline
\end{tabular}


refinement. In our calibration and validation procedure, in addition to the surveyed data from the three field campaigns, measured hourly water surface elevation data and the calculated discharge data from 1991 to 2010 were collected from Schleswig-Holstein's Government-Owned Company for Coastal Protection, National Parks and Ocean Protection (LKN-SH, 2012). The data were available at four hydrological stations: Brachenfeld (S02), Padenstedt (S09), Sarlhusen (S20) and Willenscharen (S21). Consequently, the steady flow calibration procedure involved all ten models, but the unsteady flow validation is only available for the four river sections mentioned before.

\section{Seasonal roughness coefficient}

The roughness of the river beds, banks and floodplains have been evaluated in the field and calibrated in the steady flow simulation. However the roughness conditions in the unsteady flow simulation cannot be rigorously represented based on continuous daily or hourly data due to vegetation and fluvial seasonal variations. The errors between simulated water level and real measured water level were calculated to reveal the effect of seasonal vegetation based on the daily data from 2010 . As shown in Fig. 4, the model errors were much lower after the seasonal adjustment of the roughness factors.

The seasonal roughness factors were increased when the modeled water surface elevation was lower than the real data, and were decreased while the real measured data was lower. Several rounds of calibration were completed, in order to get the most satisfying factor for minimization of the disparity (Fig. 5 and Table 2). The trends of the four seasonal roughness factor sets are similar. The roughness in March, April, November and December is lower than the general roughness by approximately $40 \%$. While in July, August, September and October the roughness is higher than the general roughness height.

\section{Model calibration}

Main attention was paid to gradient and roughness calibration, due to the difficulty of determining a representative Manning's $n$ value and the lack of river bed elevation data in the DEM model. The steady flow simulations were run for every cross section, based on the three seasonal measured data series. Strong positive correlations between HEC-RAS output and velocity, top width, maximum depth and hydraulic depth surveyed in the field were found. All the correlation coefficients were higher than 0.9 . Mean absolute relative error of velocity, top width, maximum depth and hydraulic depth of each cross section were averaged in the steady models under different water levels to evaluate the accuracy and precision of the model. The mean absolute measured errors in dry season were higher and deviated roughly 9\%-16\% from the real measured value. Relative errors in flood season varied from $3.3 \%$ to $8.9 \%$, which indicated a better model performance in flood conditions than in low water level. The best calibration results lay in moderate level season, where relative errors were less than $5 \%$.

Theoretically, unsteady flow calibration should also involve the gradient and roughness height as in the steady flow calibration. The temporal variation of river roughness tends to affect the HEC-RAS output. However, this gradient information was not available and cannot be estimated or simulated. Consequently, no more reliable and credible adjustment of this factor can be realized and roughness temporal variation is the only key adjustment in this part. Only 2010 daily data were used in unsteady roughness calibration in order to exclude the impact of the gradient variation.

\section{Model validation}

Next modeling efforts were made for validation of the measured water surface elevation. Long-term (1991-2010) daily simulations were carried out and the results are shown in Fig. 6(a). The modeled water surface elevation reflected the real measured data in general (Fig. 6(a)). The coefficients of determination $\left(\mathrm{R}^{2}\right)$ for the four models were $0.91,0.92,0.95$ and 0.99 respectively, which reflected a very high correlation between the modeled and measured data sets. The Nash-Sutcliffe efficiency varied from 0.74 to 0.82 . The mean absolute errors were around $7 \mathrm{~cm}$ in S02 and S09, and as high as $15 \mathrm{~cm}$ in the other two models. The main inconsistency occurred during dry season, where the measured data was higher than the modeled data (Fig. 6). During flood season in particular the peak flow simulations are not consistent with the observed data. The simulated elevation was lower than the measured elevation in S02 and S20, while the opposite situation was revealed in S09 and $\mathrm{S} 21$.

The quality of the validated model outputs under different water levels were shown in the Table 3. The Nash-Sutcliffe efficiency was highest during bankfull condition, but lowest during moderate conditions. During flood condition the NashSutcliffe efficiency was as high as 0.81 . These efficiencies reflected the well performance of the model at all flow conditions.

\section{MODEL RESULTS}

Temporal distribution of discharge and unit stream power Stream power under moderate, bankfull and peak discharge conditions

The importance of the bankfull hydraulics has been recognized in prior research (Vocal Ferencevic and Ashmore, 2012). The 10-year-averaged mean value of the river discharge and power reflect the moderate conditions of selected river conditions, while the discharge and the unit stream power under 10year-peak flow represent the hydraulic environment under high level flood conditions. In this part of our research, the discharge and unit stream power were standardized against bankfull values to examine the variation of river under representative conditions. The highest daily discharge of each sub-catchment during 2000-2010 was picked up as 10-year-peak discharge, and the results are shown in Fig. 7. The variations of stream discharge and unit power have similar trends. Stream discharge and unit power under 10-year-averaged conditions were around $1 / 3$ of that under bankfull discharge conditions, and the 10year-peak discharge and unit power were nearly 1.6 times higher than that of the corresponding bankfull variables.

\section{Increase rate of the in-channel and floodplain unit stream power}

As shown in Fig. 8 (a) and (b), the in-channel unit stream power is proportional to the increase of the flow discharge. All the power/discharge plots from 10 reaches can be described by exponential or logarithmic fitting curves with $\mathrm{R}^{2}$ higher than 0.85 . The averaged unit power increasing rate of in-channel flow is $1.29 \mathrm{~N} / \mathrm{ms}$ per unit discharge, as shown in Table 4. There were no flood events on reach S16 during the simulation period. 

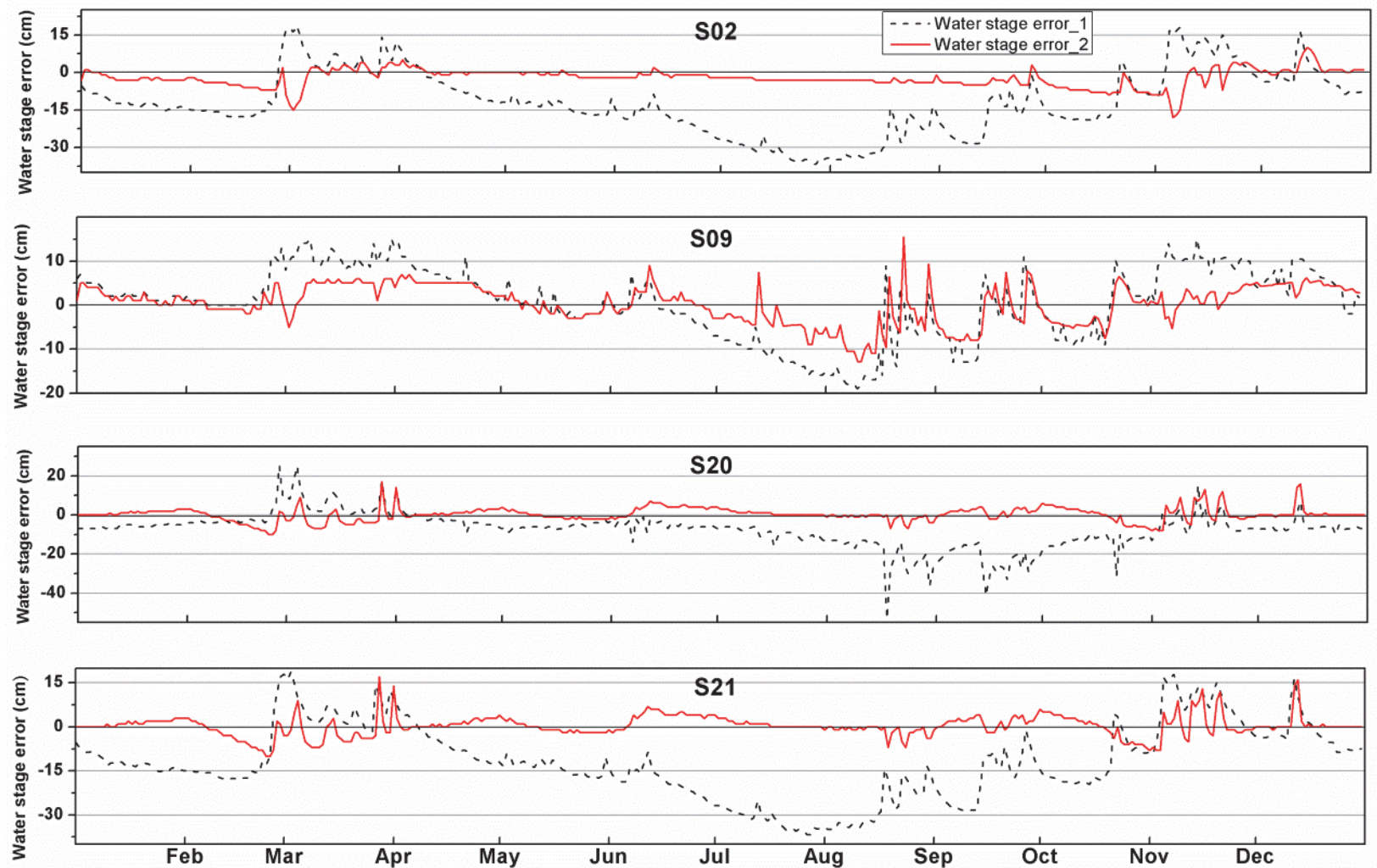

Note: Water stage error_1- error under general mean roughness condition; Water stage error_2-error under seasonal roughness conditions.

Fig. 4. Model errors under different roughness conditions.

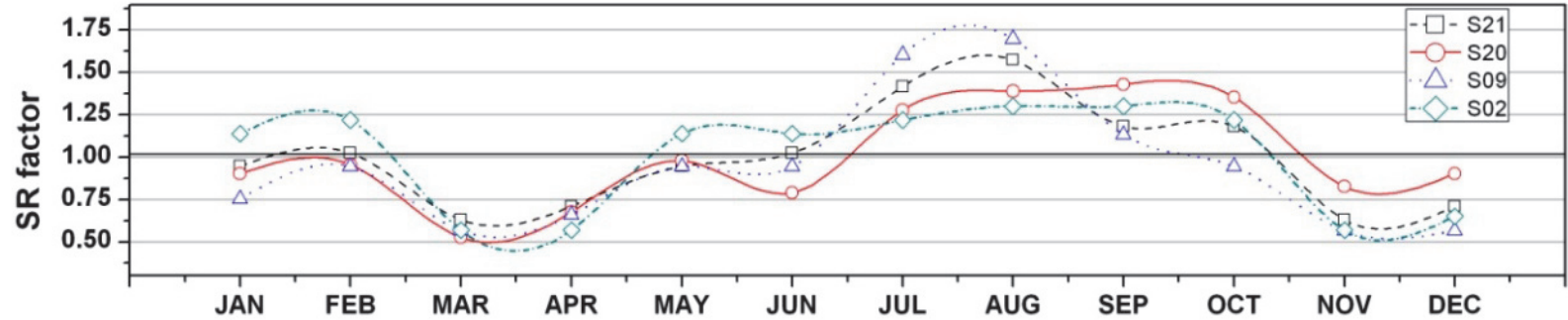

Fig. 5. Seasonal roughness factors of calibration points.

Table 3. The Nash-Sutcliffe efficiencies under different flow conditions.

\begin{tabular}{cccc}
\hline Flow conditions & Moderate & Bankfull & Flood \\
\hline Nash- Sutcliffe efficiencies & 0.76 & 0.87 & 0.81 \\
\hline
\end{tabular}

Table 4. Mean power increase rate of the in-channel flow and flood flow.

\begin{tabular}{cccccccccccc}
\hline & S02 & S03 & S07 & S09 & S10 & S12 & S16 & S17 & S20 & S21 & Mean \\
\hline In-channel flow & 0.76 & 4.4 & 0.55 & 0.42 & 2.3 & 1 & 1.83 & 0.53 & 0.44 & 0.7 & 1.29 \\
Flood flow & 0.55 & 0.66 & 0.24 & 0.25 & 0.75 & 0.09 & - & 0.14 & 0.09 & 0.27 & 0.34 \\
\hline
\end{tabular}

Table 5. The correlation results of the stream power and the slope and roughness in sub-catchment.

\begin{tabular}{lrrc}
\hline $\begin{array}{l}\text { Correlation } \\
\text { coefficient }\end{array}$ & \multicolumn{2}{c}{ Increase rate } & Flood stream power \\
\hline Slope & -0.09 & 0.57 & $(\%)$ \\
Roughness & $\mathbf{- 0 . 8 4}$ & $\mathbf{0 . 8}$ & -0.77 \\
\hline
\end{tabular}



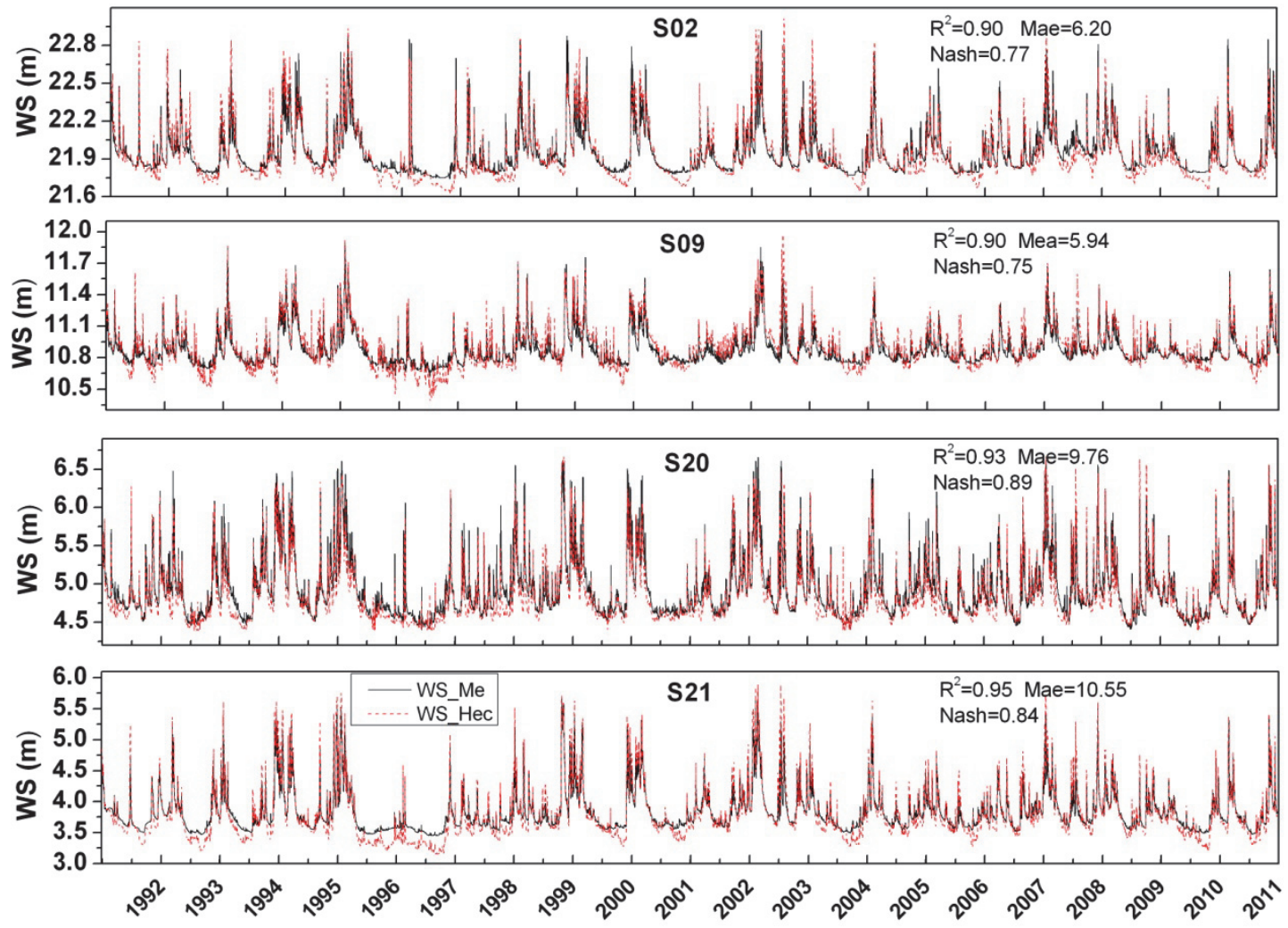

Note: Mae means absolute error of the water surface elevation; Nash, Nash-Sutcliffe efficiency.

Fig. 6. Daily measured and HEC-RAS output water surface elevation from 1991 to 2010.

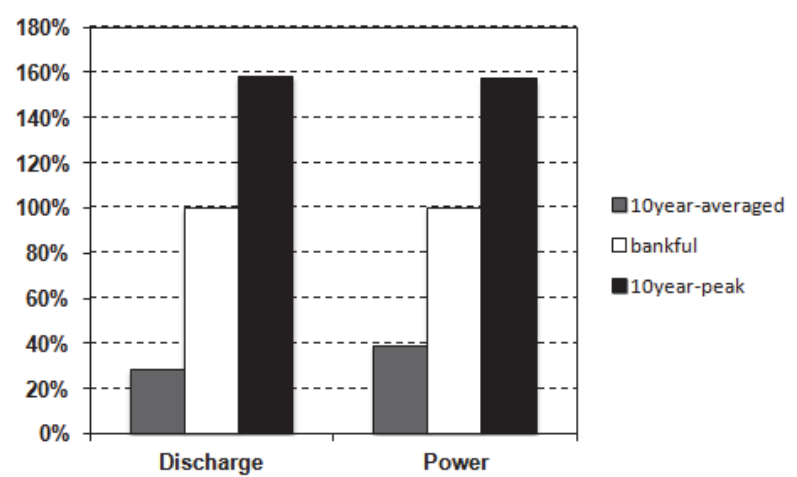

Fig. 7. Standardized hydraulic variables under representative flow conditions.

The unit stream power on the floodplain from the other 9 reaches seems to linear correlated to the flood discharge. Linear fitting analysis provided an increasing rate of the power on the floodplain (Table 4.). The mean values show that the in-channel power grows 3 times more than the flood stream power with the same increase of discharge.

\section{The lateral distribution of unit stream power}

The section-averaged in-channel unit stream power is 4.34 $\mathrm{N} / \mathrm{ms}$ with a discharge of $7.95 \mathrm{~m}^{3} / \mathrm{s}$, while the overbank flow generated $0.18 \mathrm{~N} / \mathrm{ms}$ with a discharge of $2.6 \mathrm{~m}^{3} / \mathrm{s}$. The stacked column in Fig. 9 shows the distribution of the hydraulic discharge and energy on the floodplain and in the channel. Fig. 9(a) clearly shows that the flood energy accounts for $1 \%-10 \%$ of the total stream energy. The flood energy percentage is the highest at the outlet at river section S21. According to Fig. 9(b), despite the very low energy the produced flood, around $40 \%$ of the total cross-sectional discharge distributed on the floodplain. On average, $95 \%$ of the power is concentrated in the main channel, and $5 \%$ of the power distributed on broadly on the floodplain.

\section{DISCUSSION \\ Model calibration and validation}

The smallest deviation between measured data and modeled data was revealed in the steady flow calibration part, during the medium water level season. One possible reason for this phenomenon is that the systematic field work was carried out in the moderate water level season. Although the hydraulic measurements were repeated in 2012, errors were inevitable, due to the vegetation alteration and inaccuracies in identifying precisely the same cross section in the field. After the calibration and validation, the simulated results generally fit the measured data. The simulation errors varied from $-50 \mathrm{~cm}$ to $30 \mathrm{~cm}$, but $90 \%$ of the errors were distributed within $\pm 15 \mathrm{~cm}$. Simulated output lower than measured data was identified under low water level conditions. The errors during flood seasons were lower than that during dry seasons. Similar results were found from a model set up for the NyI river in Africa, where the disparity between modeled and measured data appeared mostly in dry season (Birkhead et al., 2007). Another case study in India revealed the highest estimation quality during flood modeling, as the computed errors were only around $5.42 \%$ (Parhi, 2013). The measured water surface elevation was about $30-50 \mathrm{~cm}$ higher and 20-50 cm lower than the modeled data during the dry season and flood season respectively. The model worked best for estimation during high water level season. 

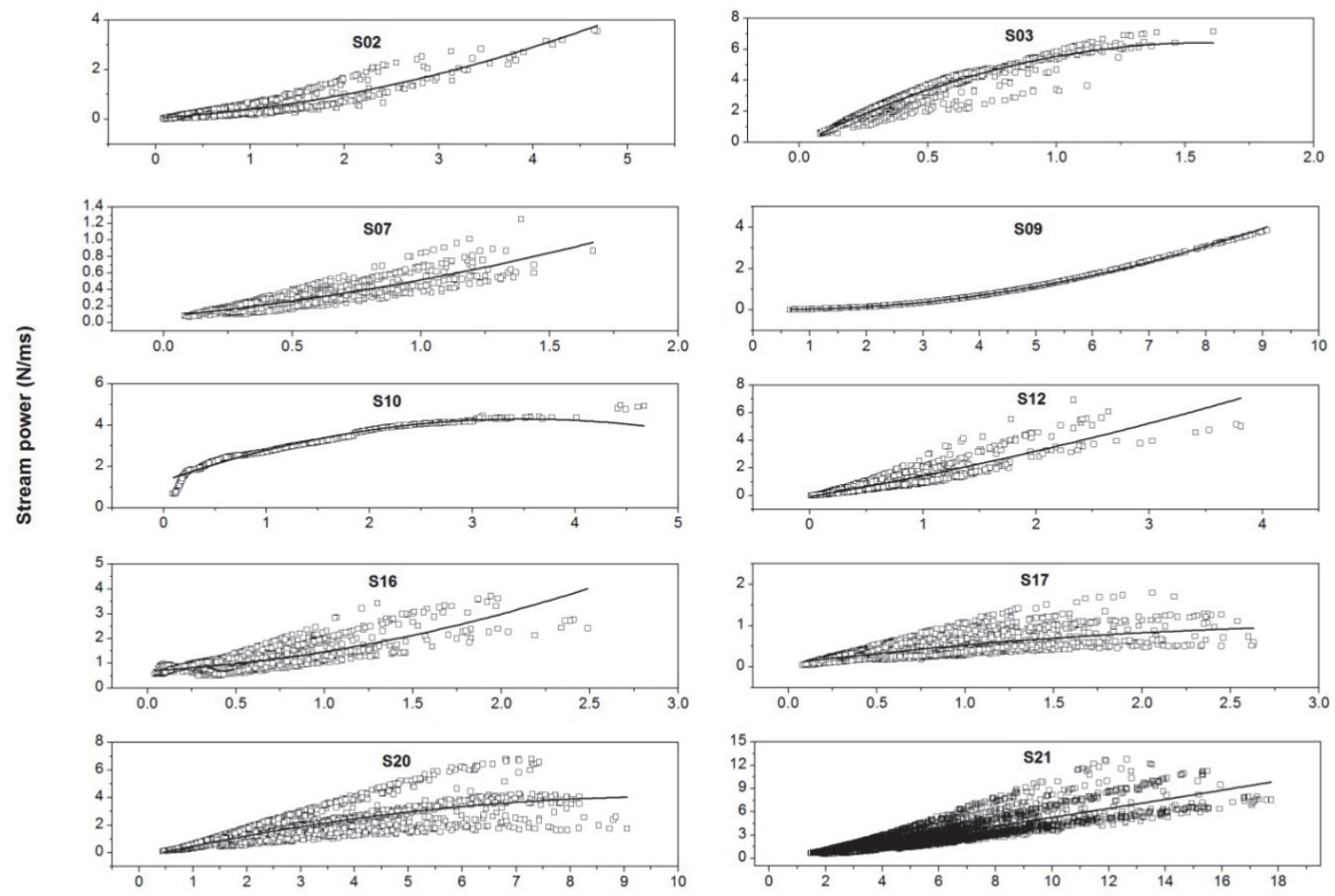

Stream in-channel discharge $\left(\mathrm{m}^{3} / \mathrm{s}\right)$

(a)
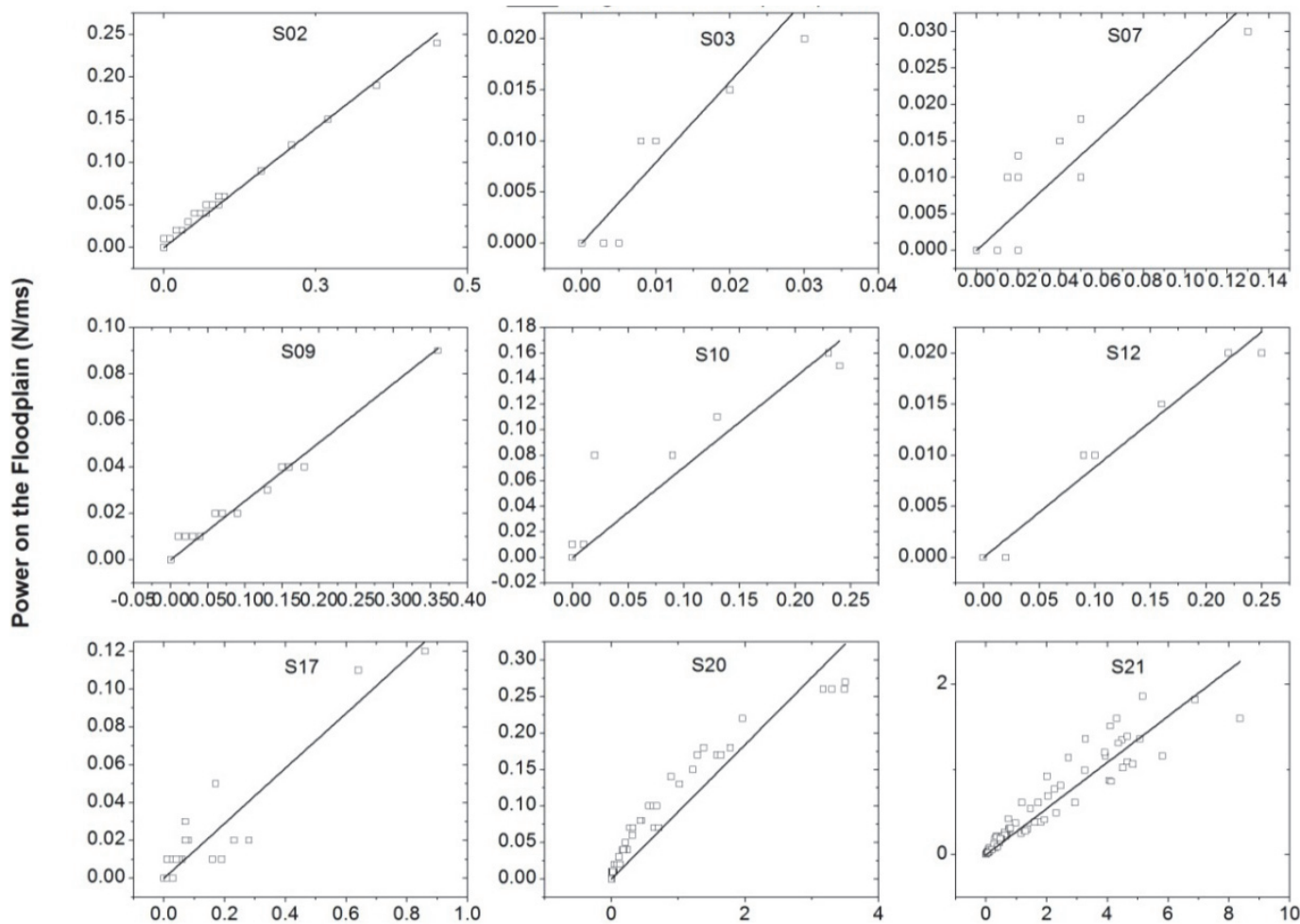

Discharge on the floodplain $\left(\mathrm{m}^{3} / \mathrm{s}\right)$

(b)

Note: The solid line is the trend line of the stream power with the increase of the discharge.

Fig. 8. Stream power plotted against flow discharge, (a) in-channel; (b) on the floodplain. 


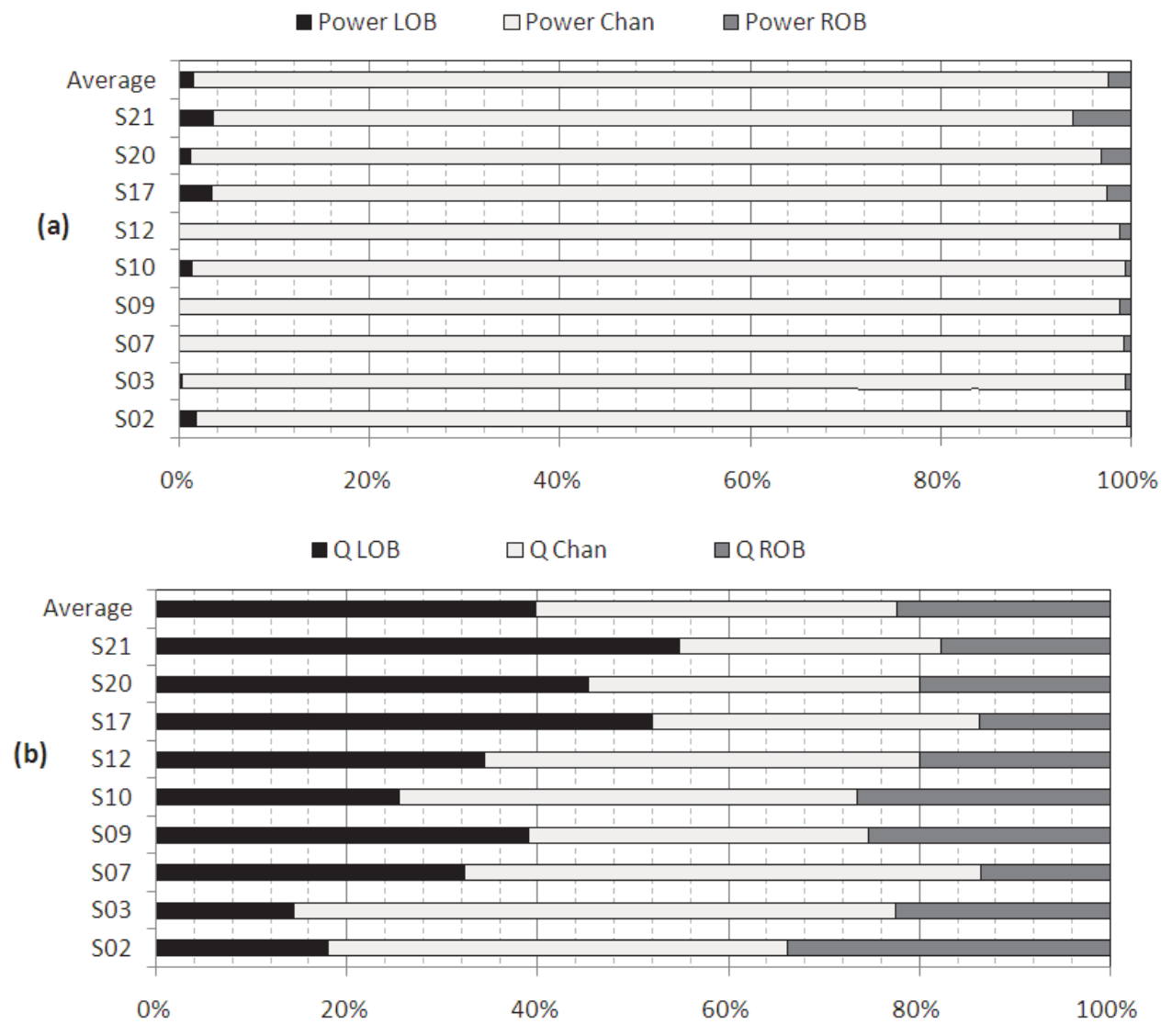

Note: LOB is the left bank of the channel; ROB is the right bank of the channel.

Fig. 9. Lateral stream power (a) and discharge (b) distribution of 10year peak flood.

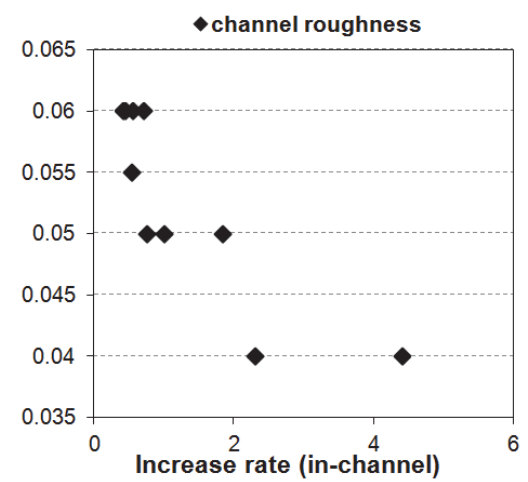

(a)

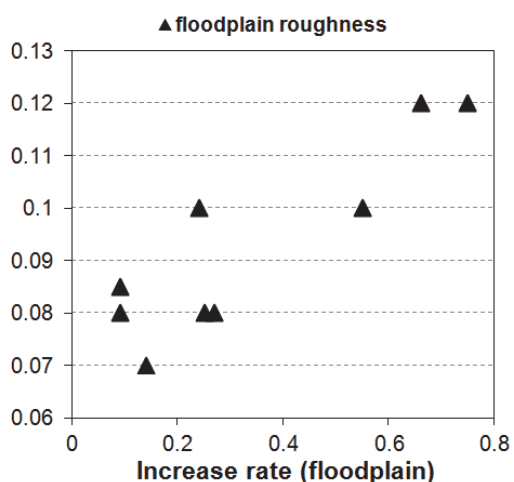

(b)

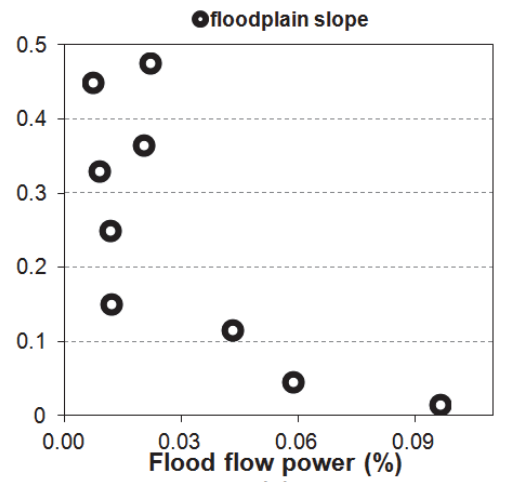

(c)

Fig. 10. Plots of the stream power against slope and roughness in sub-catchment, (a) increase rate of in-channel stream power and the channel roughness; (b) increase rate of the flood stream power and the floodplain roughness; (c) the percentage of flood stream power plot against floodplain slop.

\section{Annual variation of roughness}

The variability in roughness values attribute to differences in aquatic plant growth and the water depth (O'Hare et al., 2010; Shih and Rahi, 1982). The study in marsh area suggested that the manning roughness increased was proportional to the vegetation density and inversely proportional to the water depth (Shih and Rahi, 1982). Research in England and Scotland pointed out that the manning roughness values varied $\pm 30 \%$ from the annually mean values in summer and winter (O'Hare et al., 2010). A study from River Test, Hampshire (USACE) utilize the continuous stage records of 25 years yielded maximum roughness in August and September and then declined to its minimum value in winter months (Gurnell and Midgley, 1994). In our study, the maximum roughness values occurred during the autumn season when the biomass was at its highest amount and the water surface kept at low level. The roughness coefficient declined to minimum in flood season in March and April, because of the combination of low biomass and high water level. Weather statistic from Schleswig-Holstein showed that the averaged minimum temperature in January and February 
was $-2{ }^{\circ} \mathrm{C}$ and $-1.7{ }^{\circ} \mathrm{C}$ respectively (Climatemps, 2013). It is reasonable that the roughness increased because of the increase of the viscosity of the water body when it started to freeze.

\section{Bankfull discharge hydraulics}

Stream power and shear stress are the key variables for the formation and evolution of fluvial systems. Stream hydraulics under bankfull discharge are considered to be even more significant, because it makes the homogeneous comparisons between different river sections available (Marchi et al., 2010a). In the Upper Stör catchment, the unit stream power under bankfull discharge of each river section varied from $0.4 \mathrm{~N} / \mathrm{ms}$ to 5.85 $\mathrm{N} / \mathrm{ms}$. A series of researches studies carried out in gravel-bed rivers in Belgian Ardenne catchment, which has a similar catchment size with the Upper Stör catchment produced much higher bankfull unit stream power, from $17 \mathrm{~N} / \mathrm{ms}$ to $126 \mathrm{~N} / \mathrm{ms}$ (Petit et al., 2005). The quite marked slope in the Ardenne catchment varying from $5 \%$ for head water streams to around $0.2 \%$ for large downstream rivers assumes to be the proper explanation for the much higher unit stream power. Through bankfull condition comparison, it is clear that the rivers in the Upper Stör catchment yield very low power because of the flat and broad lowland characteristic.

The prior studies about hydraulic characteristics of inchannel flow mainly focus on downstream variation in spatial scale. Earlier studies predicted that the position of the maximum stream power turns out at intermediate positions, and the exact position depends on the ratio of discharge change and slope change in the downstream part of the catchment (Knighton, 1999). Very little literature has been found about the variation of the unit stream power with the channel discharge variation.

\section{The increase rate of the in-channel flow and the cross sec- tion geometry}

The different increasing pattern of the in-channel flow in different sub-catchments was mainly caused by cross section conditions. As we can see from Fig. 8(a), the plots of S09 and S10 showed more distinct relationship than that from the other sites due to the regular geometry of the artificial constructed cross sections. The cross section from S09 was trapezium shaped with big stone, while the cross section from S10 was in rectangle shape and constructed with concrete. No seasonal vegetation interference the flow condition at both cross sections.

The plots from S03, S10, S17 and S20 obviously showed the logarithmic trend, while the rest can be descript in exponential fitting lines as shown in Fig 8(a). This was mainly caused by the shape of the cross sections in different sites. The cross sections from S03, S10, S17 and S20 were in rectangle shape, while the cross sections from the other sires were in trapezium shape.

\section{The different flow patterns among the sub-catchments}

The roughness coefficient and slope both in-channel and on the floodplain of our studied sub-catchments covered a wide range (Table 1). The variation of the in-channel roughness coefficient mainly depended on the sediment size and the density of plantation, while the floodplain roughness was governed by the land use pattern. The local channel and floodplain slope ware calculated in the $1 \mathrm{~m}$ DEM. The combination of the local roughness heights and slope determined the sub-catchment hydrological conditions.

The correlation analysis was carried out between the stream power and the sub-catchment characteristics to find out the influencing factors of the stream power patterns among different sub-catchments. The results were shown in Table 5 and Fig. 10. The increase rate of the in-channel stream power was highly inversely correlated with the channel roughness, with a correlation coefficient valued at 0.84 . At the same time the highly positive correlation between the increase rate of flood flow and floodplain roughness was detected. On the other hand, the slope differences of the river sections and floodplains weakly correlated with the increase rate of the stream power (Table 5). This suggested that variation of the flow increasing rate were mainly caused by the different channel and floodplain roughness.

According to Table 1, both the roughness height and the slope varied in a wider range on the floodplain than in the channel. Negative correlation between the flood power percentage and the floodplain slope were found, and the correlation coefficient was as high as 0.77 (Table 5). This demonstrated that the diversity of the slope among all the sub-catchments mainly affected the percentage of the stream power located on the floodplain. Relatively less stream power were located on the steeper floodplain.

\section{CONCLUSION AND OUTLOOK}

In this paper HEC-RAS models for ten selected river sections in the Upper Stör catchment were set up and calibrated with a seasonal roughness coefficient. Combined with the SWAT model output database, we evaluated the stream power both in-channel and on the floodplain. The findings are a significant reference for the sediment transportation, nutrient migration and habitat shift in lowland river system. The results clearly show that

(1) stream discharge and unit stream power varied by a larger extent under bankfull condition, 10-year-averaged mean flow condition and 10-year-peak flow condition compared with the other hydraulic parameters. The 10-year-averaged discharge and unit power were around $1 / 3$ of bankfull discharge and unit power, and the 10-year-peak discharge and unit power were nearly 1.6 times of the corresponding bankfull parameters,

(2) unit stream power was proportional to the increase of the stream discharge, while the in-channel power grew 3 times faster than the floodplain power. The dominating factor of the different increasing rate was the local roughness factor,

(3) during 10-year-peak flood, the floodplain flow can generate $40-75 \%$ of the total discharge but only $1-10 \%$ of the stream power was produced. A relatively higher percentage of stream power was located on the floodplain with lower slope.

HEC-RAS has proven to be an efficient and accurate hydraulic model, which makes a thorough examination of the channel and floodplain possible. The seasonal roughness factor adopted in our catchment minimized the model error compared with the measured data. The continuous and long-term data source advantage of the eco-hydrological SWAT model and the hydraulic modeling advantage of HEC-RAS model were integrated in our research. The findings of this study on floodplain and main channel might be a good basis for further ecologic, sedimentologic or river dynamics research. The comparison of the in-channel and floodplain hydraulic behavior of this study would provide proof for erosion and deposition processes, as well as the associated nutrient and containment transportation of the river system. 


\section{REFERENCE}

Archer, D.R., 1989. Flood wave attenuation due to channel and floodplain storage and effects on flood frequency. Floods Hydrol. Sedimentol. Geomorphol. Implic. John Wiley Sons N. Y. 1989 P:37-46.

Arnold, J.G., Srinivasan, R., Muttiah, R.S., Williams, J.R., 1998. Large area hydrologic modeling and assessment part I: model development1. JAWRA J. Am. Water Resour. Assoc., 34, 73-89.

Barker, D.M., Lawler, D.M., Knight, D.W., Morris, D.G., Davies, H.N., Stewart, E.J., 2009. Longitudinal distributions of river flood power: the combined automated flood, elevation and stream power (CAFES) methodology. Earth Surf. Process. Landf., 34, 280-290.

Bates, P.D., De Roo, A.P.J., 2000. A simple raster-based model for flood inundation simulation. J. Hydrol., 236, 54-77.

Birkhead, A.L., James, C.S., Kleynhans, M.T., 2007. Hydrological and hydraulic modelling of the Nyl River floodplain Part 2: Modelling hydraulic behaviour. Water SA, 33.

Brocca, L., Melone, F., Moramarco, T., 2011. Distributed rainfall-runoff modelling for flood frequency estimation and flood forecasting. Hydrol. Process., 25, 2801-2813.

Brunner, G.W., 1995. HEC-RAS River Analysis System. Hydraulic Reference Manual. Version 1.0.

Chow, V., 1959. Open Channel Hydraulics. McGraw-Hill, New York.

Christian, J., Duenas-Osorio, L., Teague, A., Fang, Z., Bedient, P., 2013. Uncertainty in floodplain delineation: expression of flood hazard and risk in a Gulf Coast watershed. Hydrol. Process., 27, 2774-2784.

Climatemps, 2013. Average Temperatures in Schleswig. Kiel, Germany.

Coffey, R., Cummins, E., Bhreathnach, N., Flaherty, V.O., Cormican, M., 2010. Development of a pathogen transport model for Irish catchments using SWAT. Agric. Water Manag., 97, 101-111.

Dankers, R., Feyen, L., 2009. Flood hazard in Europe in an ensemble of regional climate scenarios. J. Geophys. Res. Atmospheres, 114.

Evans, I.S., Hengl, T., Gorsevski, P., 2009. Chapter 22 Applications in Geomorphology. In: Hengl, T., Reuter, H.I. (Ed.): Developments in Soil Science, Geomorphometry Concepts, Software, Applications. Elsevier, pp. 497-525.

Gurnell, A.M., Midgley, P., 1994. Aquatic weed growth and flow resistance: Influence on the relationship between discharge and stage over a 25 year river gauging station record. Hydrol. Process., 8, 63-73.

Hervouet, J.-M., 2000. TeLEMAC modelling system: an overview. Hydrol. Process., 14, 2209-2210.

Hicks, F.E., Peacock, T., 2005. Suitability of HEC-RAS for Flood Forecasting. Can. Water Resour. J., 30, 159-174.

Horritt, M.S., Bates, P.D., 2002. Evaluation of 1D and 2D numerical models for predicting river flood inundation. J. Hydrol., 268, 87-99.

Jähnig, S.C., Kuemmerlen, M., Kiesel, J., Domisch, S., Cai, Q., Schmalz, B., Fohrer, N., 2012. Modelling of riverine ecosystems by integrating models: conceptual approach, a case study and research agenda. J. Biogeogr., 39, 2253-2263.

Jain, V., Preston, N., Fryirs, K., Brierley, G., 2006. Comparative assessment of three approaches for deriving stream power plots along long profiles in the upper Hunter River catchment, New South Wales, Australia. Geomorphology, 74, 297-317.
Johnston, J.M., McGarvey, D.J., Barber, M.C., Laniak, G., Babendreier, J., Parmar, R., Wolfe, K., Kraemer, S.R., Cyterski, M., Knightes, C., Rashleigh, B., Suarez, L., Ambrose, R., 2011. An integrated modeling framework for performing environmental assessments: Application to ecosystem services in the Albemarle-Pamlico basins (NC and VA, USA). Ecol. Model., 222, 2471-2484.

Kasper, K., 2005. Accuracy of HEC-RAS to Calculate Flow Depths and Total Energy Loss With and Without Bendway Weirs in a Meander Bend. MS Plan-B Rep. Colo. State Univ. Dep. Civ. Eng. Fort Collins CO.

Kiesel, J., Schmalz, B., Brown, G., Fohrer, N., 2013. Application of a hydrological-hydraulic modelling cascade in lowlands for investigating water and sediment fluxes in catchment, channel and reach. J. Hydrol. Hydromech., 61, 334346.

Knebl, M.R., Yang, Z.-L., Hutchison, K., Maidment, D.R., 2005. Regional scale flood modeling using NEXRAD rainfall, GIS, and HEC-HMS/RAS: a case study for the San Antonio River Basin Summer 2002 storm event. J. Environ. Manage., 75, 325-336.

Knight, D., Shiono, K., 1996. River channel and floodplain hydraulics. Floodplain Process., 5, 139-181.

Knighton, A.D., 1999. Downstream variation in stream power. Geomorphology, 29, 293-306.

Kuemmerlen, M., Domisch, S., Schmalz, B., Cai, Q., Fohrer, N., Jähnig, S.C., 2012. Integrierte Modellierung von aquatischen Ökosystemen in China: Arealbestimmung von Makrozoobenthos auf Einzugsgebietsebene. Hydrol. Wasserwirtsch., HW 56, 185-192.

Kundzewicz, Z.W., Lugeri, N., Dankers, R., Hirabayashi, Y., Döll, P., Pińskwar, I., Dysarz, T., Hochrainer, S., Matczak, P., 2010. Assessing river flood risk and adaptation in Europe-review of projections for the future. Mitig. Adapt. Strateg. Glob. Change, 15, 641-656.

Lau, T.L., Ghani, A.A., 2012. Sustainable solutions for global crisis of flooding, pollution and water scarcity. Int. J. River Basin Manag., 10, 137-138.

LKN-SH, 2012. Landesbetriebs für Küstenschutz, Nationalpark und Meeresschutz Schleswig-Holstein: Discharge and water surface elevation data. Kiel, Germany.

Luo, Y., Arnold, J., Allen, P., Chen, X., 2012. Baseflow simulation using SWAT model in an inland river basin in Tianshan Mountains, Northwest China. Hydrol. Earth Syst. Sci., 16, 1259-1267.

LVermGeoSH, 1995. Landesamt für Vermessung und Geoinformation Schleswig-Holstein: Digitales Geländemodelle 1 (DGM 1). Kiel, Germany.

Marchi, L., Borga, M., Cavalli, M., Gaume, E., 2010a. Stream power of selected recent flash floods in Europe, in: EGU General Assembly Conference Abstracts. Presented at the EGU General Assembly Conference Abstracts, p. 10226.

Marchi, L., Borga, M., Preciso, E., Gaume, E., 2010b. Characterisation of selected extreme flash floods in Europe and implications for flood risk management. J. Hydrol., 394, 118133.

Navratil, O., Albert, M.-B., Hérouin, E., Gresillon, J.-M., 2006. Determination of bankfull discharge magnitude and frequency: comparison of methods on 16 gravel-bed river reaches. Earth Surf. Process. Landf., 31, 1345-1363.

O’Hare, M.T., McGahey, C., Bissett, N., Cailes, C., Henville, P., Scarlett, P., 2010. Variability in roughness measurements for vegetated rivers near base flow, in England and Scotland. J. Hydrol., 385, 361-370. 
Pappenberger, F., Beven, K., Horritt, M., Blazkova, S., 2005. Uncertainty in the calibration of effective roughness parameters in HEC-RAS using inundation and downstream level observations. J. Hydrol., 302, 46-69.

Parhi, P.K., 2013. HEC-RAS Model for Mannnig's Roughness: A Case Study. Open J. Mod. Hydrol., 03, 97-101.

Parhi, P.K., Sankhua, R., Roy, G., 2012. Calibration of channel roughness for Mahanadi River (India) using HEC-RAS model. J. Water Resour. Prot., 4.

Petit, F., Gob, F., Houbrechts, G., Assani, A.A., 2005. Critical specific stream power in gravel-bed rivers. Geomorphology, 69, 92-101.

Petrow, T., Merz, B., 2009. Trends in flood magnitude, frequency and seasonality in Germany in the period 19512002. J. Hydrol., 371, 129-141.

Posey, J., 2009. The determinants of vulnerability and adaptive capacity at the municipal level: Evidence from floodplain management programs in the United States. Glob. Environ. Change, 19, 482-493.

Pott, C.A., 2014. Integrated monitoring, assessment and modeling of nitrogen and phosphorus pollution in a lowland catchment in Germany - A long-term study on water quality (PhD thesis). University of Kiel, Kiel, Germany.

Rhoads, B.L., 1987. Stream Power Terminology. Prof. Geogr. 39, 189-195.

Schmalz, B., Kuemmerlen, M., Strehmel, A., Song, S., Cai, Q., Jähnig, S., Fohrer, N., 2012. Integrated modeling of aquatic ecosystems in China: ecohydrology and hydraulics. Hydrol. Wasserwirtsch., HW 56, 169-184. (in German)

Shih, S.F., Rahi, G.S., 1982. Seasonal variations of Manning's roughness coefficient in a subtropical marsh. Trans. ASAE, $25,116-119$.
Song, S., Schmalz, B., Hörmann, G., Fohrer, N., 2012. Accuracy, reproducibility and sensitivity of acoustic Doppler technology for velocity and discharge measurements in mediumsized rivers. Hydrol. Sci. J., 57, 1626-1641.

Sponseller, R.A., Grimm, N.B., Boulton, A.J., Sabo, J.L., 2010. Responses of macroinvertebrate communities to long-term flow variability in a Sonoran Desert stream. Glob. Change Biol., 16, 2891-2900.

Strehmel, A., 2011. Model-based Hydraulic Analysis of Flow and Sediment Transport in the Changjiang Basin in the Poyang Lake Region, China. University of Kiel, Kiel, Germany.

Thuiller, W., 2003. BIOMOD - optimizing predictions of species distributions and projecting potential future shifts under global change. Glob. Change Biol., 9, 1353-1362.

Vocal Ferencevic, M., Ashmore, P., 2012. Creating and Evaluating Digital Elevation Model-Based Stream-Power Map as a Stream Assessment Tool. River Res. Appl., 28, 13941416.

Wu, N., Tang, T., Fu, X., Jiang, W., Li, F., Zhou, S., Cai, Q., Fohrer, N., 2010. Impacts of cascade run-of-river dams on benthic diatoms in the Xiangxi River, China. Aquat. Sci., 72, 117-125.

Yang, J., Townsend, R.D., Daneshfar, B., 2006. Applying the HEC-RAS model and GIS techniques in river network floodplain delineation. Can. J. Civ. Eng., 33, 19-28.

Zhang, H., 2011. Sedimentation and Phosphorus Deposition in a Wetland Stream Complex (Duvenseebachniederung, Ritzerau). University of Kiel, Kiel, Germany.

Received 18 October 2013 Accepted 28 February 2014

Note: Colour version of Figures can be found in the web version of this article. 